\title{
THE CHILD LABOR PROVISIONS OF THE FAIR LABOR STANDARDS ACT
}

\author{
Katharine Du Pre Lumprin*
}

On five occasions Congress has attempted to bring federal regulation to bear on the child labor problem. The Owen-Keating Law of 1916 prohibited the shipment in interstate commerce of goods on which the labor of children under I4 years of age had been employed within 30 days, or the labor of children between 14 and 16 more than 8 hours a day. The law, admirably administered by the Children's Bureau of the United States Department of Labor, was in effect only nine months, between September, I9I7, when it became operative, and June, I9I8, when the Supreme Court by a five-to-four decision affirmed a district court ruling declaring it unconstitutional. ${ }^{1}$ There followed the Federal Child Labor Tax Law of I9I9, administered by the Treasury Department. It remained in force somewhat longer than the first act. But on May I5, I922, it too was invalidated by a decision of the Supreme Court.2

Still another mode of regulation was attempted in 1933, under the National Industrial Recovery Act. Most of the codes of fair competition were drawn to include a clause prohibiting child labor under I6. Estimates have it that between 75,000 and I00,000 child laborers were withdrawn from industry under the codes. When there came the Supreme Court's decision abrogating the N.I.R.A. in I935, this form of child labor regulation likewise disappeared. ${ }^{3}$

Meantime, confronted by the difficulty of drawing a federal law within the constitutional interpretations given by the Supreme Court, Congress in r924 had passed the Child Labor Amendment. Its adoption would remove all question of Congressional power to legislate on this pressing social problem. Ratifications of the Amendment were relatively few until the economic crisis of 1929 , throwing millions of adult wage earners out of employment, brought sharply to public attention the absurdity of permitting child labor when widespread unemployment was a recurring phenomenon. In quick succession a number of states ratified the amendment, until by r937 the total had reached 28 , only eight short of the required number.

- A.B., 1915, Brenau College; M.A., I919, Columbia University; Ph.D., 1928, University of Wisconsin. Director of Research, Council of Industrial Studies, Smith College, since 1932. Co-author, with Dorothy W. Douglas, Child Workers in America (1937); author, Shutdowns in the Connecticut Valley (1935), and The Family: A Study of Member Roles (1933). Contributor to journals on social and economic subjects.

${ }^{1}$ Hammer v. Dagenhart, 247 U. S. 25 I (I918).

2 Bailey v. Drexel Furniture Co., 259 U. S. 20 (1922). See I Absott, The Child and the State (1938) 483-525.

Id. at 557-559. 
The chances of rapidly bringing the campaign to a successful conclusion seemed bright. But the Child Labor Amendment also was thrown upon the lap of the Supreme Court by actions in Kentucky and Kansas. ${ }^{4}$ Legislative ratification in both states was challenged on the score that the legislatures had previously rejected the amendment; and in any case, it was claimed, ratification had not taken place within a reasonable period after Congressional enactment. The Kansas Supreme Court held that ratification by the Kansas legislature was valid, while Kentucky's highest court took the opposite view. Both cases were appealed to the United States Supreme Court where they were argued in October, I938. On June 5, I939 the Court rendered a decision upholding the validity of the ratifications.

The latest attempt by Congress to regulate child labor got under way in 1937. For a time it seemed probable that a law might be passed dealing specifically with the problem. Child labor measures-of very unequal merit, to be sure,-were introduced in both Senate and House. What finally eventuated was the inclusion of child labor provisions in the pending Fair Labor Standards Act. These provisions have now been operative since October 24, I938.

\section{Statutory Provistons}

The portions of the Fair Labor Standards Act dealing specifically with child labor are Sections 3(1), defining what constitutes "oppressive child labor," I2(a), prohibiting oppressive child labor, I2(b) vesting administration and enforcement of the child labor provisions in the Children's Bureau, and $\mathrm{r}_{3}(\mathrm{c})$ exempting certain classes of child labor which otherwise would come under the Act. The Act being based upon the power of Congress to regulate interstate and foreign commerce, only child laborers who are engaged in interstate industries are affected by its terms.

According to Section 3(1), it is "oppressive child labor" when a minor under the age of $I 6$ years is employed, unless the employer is the child's parent or guardian, and even a parent or guardian may not employ the child in manufacturing or mining occupations. For children under 16 years manufacturing and mining are banned in all circumstances. Children of $I_{4}$ and $I_{5}$ employed in non-mining and non-manufacturing occupations are not deemed to be employed at oppressive child labor, if the Chief of the Children's Bureau determines that such occupations do not interfere with the child's schooling or impair his health and well-being. Minors between the ages of 16 and 18 are considered engaged in oppressive child-labor occupations if such occupations have been designated by the Chief of the Children's Bureau as hazardous. It is provided that employers may secure age certificates issued under the authority of the Children's Bureau, showing that minors in their employ are "above the oppressive child-labor age."

Section I2(a) declares that "no producer, manufacturer or dealer" is permitted to send into interstate commerce "any goods produced in an establishment in the United States in or about which within thirty days prior to the removal of such goods

4Wise v. Chandler, 270 Ky. x, 108 S. W. (2d) ro24 (1937); Coleman v. Miller, 146 Kans. 390, 71 P. (2d) 518 (1937). The decisions of the Supreme Court in these two cases are found in 59 Sup. Ct. 992 and 973, respectively. See ABBotr, op. cit. supra note 2, at 468-469. 
therefrom any oppressive child labor had been employed." Already, as we shall see, interpretations of this clause have been rendered by the Solicitor of the Department of Labor restricting its application to some extent.

There are several general exemptions from the Act. Besides the clause in Section 3(l) exempting children working for parent or guardian, Section $\mathrm{I3}$ (c) exempts children employed in agriculture "while not legally required to attend school," and also children employed as actors in motion pictures or theatrical productions. These exemptions are in addition to the sweeping exclusion of child laborers engaged in occupations other than those producing for interstate commerce.

It is specifically provided in Section I2(b) that the Children's Bureau, beside being responsible for general administration of the child labor provisions, shall be responsible where minors are concerned for making investigations and inspections as provided in Section II, and also shall bring actions under Section I7, which provides for injunction proceedings, the latter, as is customary, under the direction of the Attorney General. In addition, Section II(b) provides for cooperation with state and local agencies on the part of the Children's Bureau in carrying out the purposes of the child labor provisions. Penalties (Section 16) are the same for all convictions under the Act, namely, a fine of not more than $\$ 10,000$ and/or imprisonment for not more than six months, with the additional proviso in Section I2(a), the child labor section, against the institution of a second prosecution while one is already pending.

Such in brief are the provisions of the Act touching child labor. From this point our inquiry turns upon the question, How adequate is the law to regulate child labor? For one thing, how adequate are its provisions for enforcement? Weak enforcement, we know, can in effect nullify social legislation. Secondly, to what extent does the law really cover the problem of child labor?

\section{Administration}

When the Fair Labor Standards Act placed administration of the child labor provisions in the hands of the Children's Bureau it brought a great sense of relief to all who were concerned to see competent, unbiased enforcement in a spirit of public service. Obviously, this was the administrative arrangement that should be made. Hardly had the measure become law when the Bureau was able to set in motion the machinery for implementing the child labor provisions. Behind it was the valuable experience of administering the I9I6 law, the principal features of which were similar to the $193^{8} \mathrm{Act}$. Also its staff of experts were able to draw upon their firsthand knowledge of new practices as these had developed in the several states during the past twenty years. Responsibility for administration was allocated to the Industrial Division of the Bureau, enlarged to care for the new law. An Assistant Director in Charge of Child Labor Administration was appointed.

It is to be noted from the outset that the basic elements for effective administration are contained in the child labor provisions of the Act. In building its adminis-

\footnotetext{
"Section $3(j)$ of the Act defines "produced" to mean when an employee "was employed in producing, manufacturing, mining, handling, transporting, or in any other manner working on such goods. . .."
} 
trative structure around the framework thus provided, the Bureau saw its work falling into four categories. ${ }^{b}$ It must make provision for issuing age certificates. It has long been recognized that a system of age certification is essential to enforcement of child labor laws. While section $3(\mathrm{l})$ of the Act differs from most state laws in that employers are not required to have on file certificates of age for all minors employed, it is plainly to their advantage to do so, as a protection against unwitting violation of the law. The Children's Bureau is required to make available such certificates, and we may assume that most employers will avail themselves of the protection the provision affords.

The Bureau must also make inspections for purposes of enforcement. There can be no real enforcement of labor laws unless the public agency has the power to inspect establishments and is furnished funds to employ inspectors. One of the devices sometimes resorted to in the early years of state child labor legislation, if a law could not be defeated by its opponents, was to strip it of enforcement machinery. The Fair Labor Standards Act was careful to make provision for inspection and inspectors.

The other two fields of child labor administration involve extended investigation as a preliminary step. Investigation must precede determination of the hazardous occupations from which boys and girls between 16 and 18 years should be barred; also the determination of certain aspects of employment conditions in non-mining and non-manufacturing occupations for boys and girls of $\mathrm{I}_{4}$ and $\mathrm{I5}$.

In the Bureau's own words, it has taken as the keynote of its administration of the Act the strengthening of state services through federal-state cooperation. ${ }^{7}$ It is hard to see how enforcement could be successful without this. Not only does it prevent duplication, and hence make for efficient service; it spells the difference between insufficient staff, which would certainly be the case if the Bureau had to depend largely upon its own budget, and the fairly adequate service made possible through collaboration with state child welfare staffs.

A first step of the Bureau was to enlist the aid of state agencies in the issuance of temporary certificates of age. The standards set down in Regulation Number I are those commonly observed by the better state administrations. They turn in the first place upon what shall constitute proof of age. According to this regulation, proof of age should, whenever possible, be based upon a birth certificate or official transcript issued by an officer charged with the duty of recording births. Other evidence of age may not be accepted by an officer issuing certificates according to federal standards unless proof is furnished that an official birth certificate cannot be provided. In the latter case other evidence may be accepted, such as a record of baptism, or a bona fide, contemporary record, provided it has been in existence at least one year prior to the time it is offered. In certain cases a school record showing the age of the minor will be recognized, provided it is accompanied by the sworn state-

${ }^{\circ}$ U. S. Children's Bureau, Children's Bureau program in administration of child-labor provisions of the Fair Labor Standards Act (Typewritten memorandum), March 15, 1939.

${ }^{7}$ Ibid. 
ment of parent or guardian, and also a certificate from a physician testifying that he believes the physical age of the minor is as alleged. ${ }^{8}$

However good the standards for age certification, they cannot accomplish their purpose unless the certificating agents themselves are competent officials. Some state services are still weak in this regard. ${ }^{9}$ However, if we may judge by the brief period of federal regulation under the rgr6 law, the influence of federal standards of administration will tend rather quickly to bring improvement in such states. ${ }^{10}$

In the case of those states whose standards substantially conform to a federal level, the Bureau's procedure has been to designate appropriate agencies within the state to issue state certificates of age; these thereupon have the validity of federal certificates. In certain states where certificating systems do not quite come up to a federal level the Bureau has designated state agencies temporarily to issue certificates valid under the federal law, pending improvement in their state systems. ${ }^{11}$ When state laws do not provide for employment certificates, then arrangements must be made for issuing federal certificates either directly by a federal agent or through some existing state agency.

The procedure now being followed closely parallels that used by the Bureau in the administration of the Child Labor Law of Igr6. Today, however, the task is much easier due to improvement in state standards during the intervening twenty years. When the Igr6 law became operative, while 39 states and the District of Columbia were designated to issue age certificates for the first six-months period, at the end of six months, only I3 states were redesignated for a I2-months period, while 22 were continued for only six months and two were approved for but three months. The Bureau itself issued federal certificates in North Carolina, South Carolina, Georgia and Mississippi, and later in Virginia, because in these states certificating systems were nonexistent or else too far below federal standards to accept. ${ }^{12}$

Within a month after the Fair Labor Standards Act of 1938 became operative, appropriate agencies in $4 \mathrm{I}$ states and the District of Columbia had been designated to issue certificates of age according to their usual procedures, these to be given the validity of federal certificates. ${ }^{13}$ By April, I939, one more state had been added, making 42. The first order was for a period of six months; by a regulation issued April 24, I939, it was extended to November I, I939. ${ }^{14}$

In the six states without appropriate certificating systems, the situation is being handled as follows: In Idaho the state law does not provide for employment certificates to minors, but the Bureau has arranged for the State Department of Public

\footnotetext{
${ }^{8}$ U. S. Children's Bureau, Child Labor Regulations, Regulation No. r, Certificates of Age, October I4, I938; also Regulation No. I-A, Temporary Certificates of Age, and Regulation No. I-B, extending the date of temporary certificates of age regulation.

- White House Conference of Child Health and Protection, III D, Child Labor, Rebott of Subcommittee on Child Labor (1932) $4 \mathrm{Ig}$ ff.

${ }^{10}$ Aввот, op. cit. supra note 2, at $486-495$.

11 U. S. Children's Bureau, Child Labor Regulations, Regulation No. 1.

12 ABвotr, op. cit. supra note 2, at 489-490.

${ }^{23}$ McConnell, Child Labor and the Fair Labor Standards Act (1939) 6 LAB. INF. Bull. No. 2, p. 10.

' U. S. Children's Bureau, Child Labor Regulations, Regulation No. xo, Acceptance of State Certificates.
} 
Instruction to issue federal certificates. ${ }^{15}$ In Mississippi federal certificates of age are issued through an office set up in Jackson. ${ }^{16}$ For the four remaining states, Iowa, Louisiana, North Dakota and Texas, the Bureau is in process of making arrangements. ${ }^{17}$

Employers are advised to obtain certificates of age for each minor 16 or 17 years old. In the case of occupations declared hazardous for minors between 16 and $\mathrm{r} 8$, the employer is to have certificates for each employee i8 or 19 years old. He may ask for certificates of age for any other young people in his employ if he has any doubt about their ages. It is thus he protects himself from involuntary violation of the Act.

For its work of inspection the Children's Bureau is able to call upon the aid of the Wage and Hour Division, which makes routine inspections of establishments producing for interstate commerce in connection with enforcement of wage and hour regulations. The Bureau has arranged with the Division to check for child labor wherever the latter's inspectors go. If apparent violations are found, then the Bureau will have its own staff take up the matter, investigate for proof of age, and do anything further that the case may require. For certain industries that do not come under the Wage and Hour Division but are covered by the child labor provisions of the Act, the Children's Bureau has to make the initial investigations. ${ }^{18}$

Officials responsible for enforcing state child labor laws can also aid in the detection of violations. So can trade unions. As an official of the Bureau has pointed out, workers are in a strategic position to know when employers are not living up to the provisions of the Act. ${ }^{19}$ If trade unions are alert to the problem, they can be of indispensible aid in bringing about strict observance.

In the determination of hazardous occupations for minors 16 and 17 years of age, the Bureau proposes to move with deliberation and caution. Its procedure envisages special studies and investigations to build up a body of accident and occupational-disease statistics touching young workers. In doing this it expects to work in close collaboration with experts, also with state accident commissions, and with employers and representatives of labor. ${ }^{20}$ It has in view the appointment of an advisory committee on occupations hazardous to minors to aid it in establishing general policies and procedures. ${ }^{21}$

Up to mid-May, 1939, only one hearing had been held to determine hazardous employments, that for the explosives industry. ${ }^{22}$ The proposed finding and order

${ }^{15} \mathrm{McConnell,} \mathrm{supra} \mathrm{note} 13$, at $\mathrm{Ir}$.

${ }^{16}$ Letter from Nicholas E. Allen, Attorney, Children's Bureau, U. S. Department of Labor, April 28, r939.

${ }^{18}$ U. S. Children's Bureau, Memorandum, stipra note 6.

${ }^{17}$ MeConnell, supra note 13 , at 11 .

10 McConnell, supra note 13 , at Ir.

${ }^{20}$ U. S. Children's Bureau, Memorandum, supra note 6; also Child Labor Regulations, Regulation No. 5, Procedure Governing Determination of Hazardous Occupations, November 4, 1938.

${ }_{21}$ McConnell, Oppressive Child Labor Is On the Way Out, January, 1938. (Mimeographed).

22 U. S. Children's Bureau, Notice of Hearing on Proposed Finding and Order Relating to the Employment of Minors Between 16 and I8 Years of Age in the Manufacture of Explosives Including Goods Containing Explosive Components Under the Fair Labor Standards Act of 1938, March I5, 1939. 
to ban the employment of minors of 16 and $I_{7}$ "from all occupations in or about any plant manufacturing explosives," defines plants to mean the land and buildings and other structures used for manufacture or processing of explosives. Explosives include ammunition, smokeless powder and all goods classified by the Interstate Commerce Commission as falling in that category.

Of especial interest in this first proposed order in the field of hazardous occupations is the type of evidence on which the finding is based. The Children's Bureau made its own investigation, from which it concluded that "despite progress in the promotion of safe working conditions," the manufacture of explosives is still hazardous in nature. Data for 1936 show the accident severity rate for explosives to be approximately twice that of the average for all manufacturing industries. Because young workers are "characteristically lacking in the exercise of caution," to work in explosives plants is peculiarly hazardous for them. Twenty-two states have recognized this fact by setting a minimum age for work in such plants higher than the general minimum. Moreover, it has been the policy of some manufacturers of explosives to refuse to hire any young workers under I8 years of age. ${ }^{23}$ The hearing was held on March 28, I939, and it is expected that a permanent order will be forthcoming.

Concerning child laborers between $\mathrm{I}_{4}$ and I6 years of age in non-mining and non-manufacturing industries for whom the Bureau must determine the work conditions that do not interfere with their schooling or well-being, it is perhaps correct to say that two different administrative problems present themselves. One has to do with the work of children in agriculture. The Act exempts such children if they do not go to the fields "while legally required to attend school." Because of this exemption we do not really know to what extent the Act actually affects agricultural child labor. Nor has the Bureau indicated yet what may be its procedure in dealing with this field.

The problem of young children in urban occupations is less complicated. School terms are fairly uniform in cities and towns, urban school authorities in most states are apt to be familiar with child labor laws and procedures, industrial establishments producing for interstate commerce are reasonably easy to get at for purposes of inspection. Altogether, enforcement can proceed along established lines.

The Bureau has issued a series of temporary regulations touching the employment of children $\mathrm{I}_{4}$ and ${ }_{5} 5$ years old, ${ }^{24}$ the first on October 2I, 1938. On February

${ }^{3}$ Ibid.

as U. S. Children's Bureau, Child Labor Regulations, Regulation No. 3, Temporary Regulation for Employment of Minors Between 14 and 16 Years of Age, October 21, 1938; Regulation No. 3-A, Amendment to Temporary Regulation ...., November 3, 1938, (making a certain clause in previous regulation of no force and effect until a public hearing had been held); Regulation No. 3-B, Extension of Temporary Regulation .... January I0, 1939 (the original regulation as amended being extended until April 24, 1939); Notice of Hearing on Proposed Regulation Relating to the Employment of Minors Between $\mathrm{I}_{4}$ and 16 Years of Age .... January 3x, 1939 (the hearing being set for February 15, 1939); Proposed Regulation as Revised, April 20, 1939 (with notice that the hearing having been held, the regulation would be published in the Federal Register, with a period of ten days allowed in which objections might be received, after which the regulation would become permanent). 
I5, I939, a hearing was held, followed by a proposed permanent regulation. According to the regulation, such child laborers are not permitted to work at "manufacturing, mining, or processing occupations, including occupations requiring the performance of any duties in work rooms or work places where goods are manufactured, mined, or otherwise processed." Nor are they permitted to work at occupations involving the "operation or tending of hoisting apparatus or of any power-driven machinery other than office machines"; nor may they operate motor vehicles or serve as helpers on motor vehicles; nor may they enter public messenger service; nor may they work at occupations that the Children's Bureau finds to be hazardous for minors of 16 and 17 .

But children of $\mathrm{I}_{4}$ and $\mathrm{I}_{5}$ may work at all other occupations in interstate industries (not counting, of course, the exempt occupations, including agriculture), within the following prescribed periods: (a) outside school hours; (b) not more than 40 hours in any one week when school is not in session; (c) not more than 18 hours in any one week when school is in session; (d) not more than 8 hours in any one day when school is not in session; (e) not more than 3 hours in any one day when school is in session; (f) between 7 a.m. and 7 p.m. in any one day, except in the distribution of newspapers; between 6 a.m. and 7 p.m. in any one day, in the distribution of newspapers, except that from April I to September 30 they may work until 8 p.m.; they may not, however, distribute newspapers "both before and after noon of any day when school is in session except between 7 a.m. and 7 p.m."

Within the terms of the Act the Bureau could ban children of $1_{4}$ and ${ }_{15}$ from occupations in other interstate industries than those now prohibited if it found such occupations to be injurious to these children. Here, as in the question of hazardous occupations, painstaking investigation must precede regulation, and the Bureau has as yet been unable to undertake inquiries in this field. ${ }^{25}$

Indeed, insofar as the Bureau is seriously handicapped on the administrative side, it would seem to be because it has insufficient facilities to carry on investigations to determine unwholesome and hazardous occupations. So the matter appears judged from the outside. Limitations of staff, we are told, make it impossible for the Bureau to study more than one industry at a time for its hazards to young workers. ${ }^{20}$ Given the long-drawn-out process that investigation and hearings entail, the prospect for early determination of hazardous employments is discouraging. What a pity that years ago the Bureau was not provided with the facilities for large-scale research in this field! Not only would it then have been ready when federal legislation came: it could have rendered a service to state child welfare agencies in their attempts to prevent serious injury to the health and safety of young workers. Merely to have been able to inform the public of the facts on hazardous occupations would have been a factor in eliminating some of the abuses.

In other respects than the foregoing the Bureau has the means of enforcing the child labor provisions of the Act with a fair degree of success. It can do so because

\footnotetext{
${ }^{25}$ Letter from Nicholas E. Allen, supra note I6. $\quad{ }^{20}$ Ibid.
} 
it is permitted to call upon the facilities of state agencies and upon those of the Wage and Hour Division.

\section{COVERAge AND EXEMPTIONS}

If the Act's coverage were commensurate with its administrative provisions we should feel that great progress had been made. Not that in it child labor regulation has stood still. Age stipulations in the Act, given the occupations to which they apply, have advanced us considerably beyond the standards at present prevailing in a number of states. At the time the Act was passed only sixteen states had 16 years as the minimum age for factory employment. In three the minimum was ${ }_{15}$, in twenty-four it was I4, while eight states still permitted exceptions to be made in the case of children under I4. In the matter of hazardous employment, 3 I states offered practically no protection to young people of $\mathrm{I} 6$ and $\mathrm{I}$, and nine provided next to none for those of $\mathrm{I}_{5}$ and less. ${ }^{27}$ By prohibiting the employment of children of $\mathrm{x} 6$ and under in manufacturing and mining, and by permitting their employment in other occupations only under conditions that do not interfere with their schooling or their general welfare, also by making possible the eventual exclusion of minors of I6 and I7 from hazardous occupations, the Act brings under a system of uniform federal regulation many children who formerly went unprotected.

Yet certain of the fields of employment that presumably come under the Act deserve careful watching. For one, there is canning. Shrimp, vegetable and fruit canneries, located in remote districts near the source of the product, carry on operations seasonally, often under haphazard conditions of production, sometimes with migratory family labor. In the past such canneries have been among the worst offenders in the employment of young child workers, those of $\mathrm{I}_{4}$ and $\mathrm{I}_{5}$ and even younger. ${ }^{28}$ In many states canneries have been exempt from the age and hour provisions of child labor laws, especially in the states where the canning industry is important. ${ }^{29}$ Patently, the products of canneries would enter interstate commerce; hence, under the terms of the Fair Labor Standards Act, child labor under 16 therein should be barred. Yet we shall have to wait to see how successfully young workers are eliminated from the canning industry. For it would appear that the question of their employment is not in the view of the industry entirely closed. So recently as May I6, I939, a very disturbing dispatch appeared in the New York Times, ${ }^{30}$ reporting attempts on the part of some Congressmen to make radical changes in the Wages and Hours Law. Representative Mary T. Norton, chairman of the House Labor Committee, is quoted as having declared that those attempting to throw the measure on the floor for far-reaching amendment represent canners and similar groups of interests.

\footnotetext{
${ }^{27}$ Binder, New Protection for the Child Laborer (1938) 23 ANs. TEACHER 15.

${ }^{28}$ Pennsylvania Department of Labor and Industry, What of Pennsylvania Canneries? (1925) х2 LA30R and Industry; U. S. Children's Bureau, Pub. No. 198, Mathews, Children in Fruit and Vegetable Canneries (1930).

${ }_{20}$ U. S. Children's Bureau, Pub. No. 197, Child Labor-Facts and Figures (1933) Chart I, pp. 56-57.

${ }^{20}$ P. 17 , col. 5.
} 
Again, young workers are employed at industrial homework. ${ }^{31}$ For this group also it is too early to tell how much protection the Act may afford, although clearly most goods produced under homework conditions would be of a kind that moves across state lines. No regulations have so far been issued by the Children's Bureau specifically dealing with the field. ${ }^{32}$ However, orders issued by the Wage and Hour Division should be of some help. Under these regulations employers engaging homeworkers are instructed to keep records showing the name and address of each homeworker, date of birth if under 19 years old, name and address of the agent through whom the work is distributed, and detailed records for each lot of work issued each week. On the homeworker's part a record book must be kept showing the work received and returned. ${ }^{33}$ However, at best, regulation of industrial homework is still in an experimental stage; the rules thus far promulgated no doubt are largely tentative. Were it found possible to enforce nothing more than the minimum wage provisions of the Act, it would not only tend to eliminate child labor, but homework itself very probably would soon disappear. Most employers would find it more profitable to carry on their manufacturing operations inside factory walls if instead of the few cents an hour they have been accustomed to pay homeworkers they had to pay a minimum wage of 25 cents.

The legislators who framed the child labor provisions of the Act apparently intended to bring children who sell and deliver newspapers under its protection. Section $\mathrm{I}_{3}$ (a) (7) exempts only those newspapers "with a circulation of less than three thousand the major part of which circulation is within the county where printed and published." Certainly it would have been a severe blow to child welfare if children employed in this industry had not been protected. Newspapers are one of the largest child-employing fields. The newspaper industry's own figures in 1934 reported more than a quarter million children under $\mathrm{I} 6$ at work as sellers and carriers. ${ }^{34}$. Yet apparently the extent to which these child laborers are protected by the Act is still an unsettled question. Under the conditions laid down in proposed Child Labor Regulation No. 3 (as revised, April 20, I939), children employed in newspaper occupations must conform to certain specified hours of work. But now an interpretation of the Act has been issued which apparently seriously curtails the scope of protection afforded these child workers. In a special order of April 12, 1939, the Chief of the Children's Bureau announces that with the approval of the Solicitor of the Department of Labor, newspapers which ship or deliver for shipment in interstate commerce "are subject to the child-labor provisions of the Act if the work of minors under the age of 16 years engaged in the distribution of such newspapers requires them to come in or about the establishment in which newspapers are produced." ${ }^{36}$ The order thus

${ }^{31}$ Lompein and Douglas, Child Workers in America (1937) 50-52.

${ }^{32}$ Letter from Nicholas E. Allen, supra note 16.

${ }^{33}$ Homework Under the Wages and Hours Act (1939) 21 AM. Chro, No. 4, p. 3.

${ }^{34}$ Folks, Changes and Trends in Child Labor and Its Control, National Child Labor Committec, Publication No. 375 , June, 1938.

${ }^{35}$ U. S. Children's Bureau, Application of the Child Labor Provisions of the Fair Labor Standards Act to Children Engaged in the Distribution and Delivery of Newspapers, April 12, 1939. (Italics mine). 
goes back to the phrase in Section I2(a) prohibiting the shipment or delivery for shipment in interstate commerce of goods produced in an establishment "in or about which" any oppressive child labor has been employed.

Only one case has so far arisen touching newspaper work and that was heard in a Michigan circuit court. ${ }^{36}$ A newsboy 13 years of age brought suit against the publishing company for which he delivered newspapers to enjoin it from terminating its contract with him. The boy, it seems, delivered papers in his own village which lay some miles distant from Lansing where the paper was published, his papers being delivered to him by truck. The Children's Bureau did not intervene in the case because the Solicitor of the Department of Labor declared that the boy's employment could not be considered to have been "in or about" the newspaper company's establishment. Similarly the court ruled that the newsboy was not an employee of the newspaper company within the meaning of the Act, because he was not employed "in or about" the publishing company's plant. Hence his case did not come under the Act, and hence the publishing company had no grounds for terminating the contract. ${ }^{37}$ This ${ }^{2} 3$-year-old boy was free to go on delivering newspapers.

Inevitably there comes to mind in this whole situation the long-familiar argument of newspaper publishers that child distributors of newspapers are not their employees but "little merchants" who hold independent contracts with them; and that hence the publishing corporations are not responsible for the conditions under which the children work. While some of the worst conditions characterizing newsboy work in the past have been associated with the establishments where children have had to wait for their papers, studies have long ago shown that street work of all kinds for young children in itself tends to be unwholesome and hazardous. ${ }^{38}$ Whatever was intended in the Act, newsboys who get their papers from trucks need its protection just as much as do those who receive them at the door of the publishing establishment. If the interpretation made in the Myers case means what it seems to mean, we have reason to fear that many children of $\mathrm{I}_{5}$, $\mathrm{I}_{4}$, and even younger, may be left outside the protection of the Act.

How limited in general is the Act's coverage is seen in the number of child workers affected by its provisions. It is estimated that some 30,000 to 50,000 minors under 16 will be withdrawn from industry as a result of the Act.39 Yet at the time the Fair Labor Standards Act was passed a total of some 850,000 children I5 years and under were gainfully employed. ${ }^{40}$ Thus the Act does not begin to deal with child labor as a mass problem. It touches at best less than 6 per cent of these younger employed children.

\footnotetext{
${ }^{30}$ Myers v. State Journal Co., C. C. H. Lab. Law Serv. G18,290 (Mich. Cir. Ct., I938).

${ }^{37}$ Letter from Nicholas $\mathrm{E}$. Allen, supra note $x 6$.

${ }^{38}$ U. S. Children's Bureau, Pub. No. 227, Children Engaged in Newspaper and Magazine Selling and Delivering (r935); Pub. No. 183, McGill, Children in Street Work (1928); see also LumPKIN AND DougLAs, op. cit. supra note $3 \mathrm{x}$, at 9-10, 45-49.

${ }^{30}$ No estimates have yet been attempted of the sumber of minors 16 and 17 years of age who may in time be banned from hazardous occupations.

${ }^{10}$ Binder, supra note 27, at 14; Folks, supra note 34 , at 24.
} 
The seat of the trouble is obvious. The largest single child-employing field is agriculture, and agriculture has virtually been exempted in the Act. Some 70 per cent of all child laborers under $x 6$ are employed in agriculture. At best, it is agreed, only a fraction of these can be protected under the Act as it now reads. In the areas where the worst abuses exist, especially in cotton and tobacco culture, and in areas where migratory family labor is largely employed, we can expect little effect. ${ }^{41}$

Many agricuitural child laborers working as members of a family group are not paid a wage directly: the pay goes to the head of the family. If they are considered to be employed by their parents, then they would not come under the Act. Moreover, whatever protection is given agricultural child labor under the Act must depend, the Bureau points out, upon the scope and enforcement of compulsory school laws in the various states, ${ }^{42}$ since children are permitted to work in agriculture "while not legally required to attend school." But it is a notorious fact that school attendance regulations in agricultural states are often extremely lax, if not waived altogether when the crops demand it. In southern rural regions, moreover, the school terms themselves are in many localities so short as to offer no real obstacle to agricultural work. And in the case of states in which migratory family labor in large numbers is employed not only is there commonly failure to enforce compulsory school laws for migratory workers' children, but some states even exclude such children legally from their schools. ${ }^{43}$

Under the broad definition given agriculture under the Act children who work in turpentine camps are exempt from its protection. The Act defines agriculture as does Section ${ }^{15}(\mathrm{~g})$ of the Agricultural Marketing Act, which in turn refers to the Naval Stores Act of March 3, I923, to include persons employed on the production, cultivation, growing or harvesting of crude gum from a living tree or in processing gum spirits of turpentine and gum rosin from crude gum. ${ }^{44}$ This industry, located chiefly in the States of the lower South, when investigated by the National Child Labor Committee in 1937, was found to employ many children under $x 6$ at low wages and very long hours. ${ }^{45}$ The conditions of work were patently unwholesome for young children. No regulation of their labor is possible as the Act reads now, except insofar as it might be found that they were employed "while legally required to attend school."

Entirely excluded from regulation by the Act are all children employed in industries and trades that are intrastate in character. Large numbers of girls under 16 years are in domestic service. Many boys and girls are in personal service trades, at work in laundries, hotels, restaurants, beauty parlors, filling stations. Many serve as clerks in stores, or are employed at messenger and clerical work of a routine kind.

\footnotetext{
labor).

${ }^{11}$ Lumpkin and Douglas, op. cit. supra note $31, c c . V$ and VI (for a discussion of agricultural child

${ }^{22}$ Letter from Beatrice McConnell, Director, Industrial Division ${ }_{\lambda}$ Children's Bureau, U. S. Department of Labor, March 16, r939.

${ }^{28}$ White Hodse CONFERENCE, op. cit. supra note 9, at $29 \mathrm{I}$ ff; Folks, supra note 34, at 24.

"Letter from Nicholas E. Allen, supra note 16.

"Sidel, Dipping Gum for "Babbitt" (1938) 20 AM. CHrD No. 2, p. I.
} 
Their hours of labor are usually long, their wages very low. Together these constitute a large body of child labor in the non-agricultural field. In fact it has been estimated that hardly more than 25 per cent even of non-agricultural child workers come under the protection of the Act. ${ }^{48}$

Since agricultural child workers under 16 years, constituting almost three-fourtl, of all gainfully employed children, are virtually exempt from the Act's provisions; and since 75 per cent of the non-agricultural group are also excluded from its terms, most of the child labor problem remains to be dealt with.

This fact is even more serious than at first appears, since the fields wherein children are today in greatest demand are those in which child labor has been increasing. In manufacturing and mining there has been a decrease in child employment during recent decades, not alone because these occupations have been the subject of regulation, but because technological changes, the introduction of new, more complex machinery, has made the employment of very young operators less advantageous. To be sure, until the passage of the Fair Labor Standards Act, children were still employed in textile mills in considerable numbers, and at miscellaneous mechanical operations. The provision of the Act banning children under $x 6$ years from all manufacturing and mining operations was sorely needed. ${ }^{47}$ In recognizing that, however, we should not forget the occupations where the demand for child labor has remained unabated, namely, in agriculture and in the intrastate, non-mechanical, urban types of work. Here where the great bulk of child laborers are found, their work remains largely unregulated.

If uniform federal regulation is to be applied to this great bulk of child wage earners, a Constitutional amendment is necessary. It should be established beyond any doubt that Congress has the power to deal with all phases of the problem. Hence, the importance of the Child Labor Amendment, pending since 1924. Now that the Supreme Court has rendered its favorable decision on the Kansas and Kentucky cases (June 5, I939), the organizations and individuals interested in eliminating harmful child labor can be free to concentrate their efforts upon obtaining the eight additional ratifications needed to complete adoption of the Amendment. Congress can then proceed to make up the deficiencies in the Fair Labor Standards Act, deficiencies that are inevitable so long as it has power to legislate on this problem only for interstate industries.

What will be done in the matter of agricultural child labor is another question. Congress could deal with this field more adequately now if it saw fit, since the major crops on which children work enter interstate commerce. The writer has treated the

\footnotetext{
"Folks, stipra note 34 , at 24.

'Up to mid-May, 1939, the Children's Bureau had taken legal action in one instance to enforce the r6-year-age minimum in manufacturing. Lenroot v. Duplan Silk Corporation, (W. D. Va., March 29, 1939). Suit was brought by the Chief of the Children's Bureau under Section 17 of the Act and in accordance with section 12 (b). The Duplan Silk Corporation, manufacturers of rayon fabric at Grottoes, Virginia, consented to the entry of a decree against it perpetually enjoining it from future violation of Section 15 (a) (4) of the Act which prohibits violations of the child labor provisions. Letter from Nicholas E. Allen, stupra note 16 .
} 
necessity for this at length elsewhere. ${ }^{48}$ Suffice it to say here that the reason agricultural occupations are exempt under state child labor laws and now under the federal law is not because the conditions under which children work in agriculture are harmless. On the contrary, special investigations have demonstrated repeatedly that it cannot be good for the health and well-being of young children ranging in age from six years up to labor extremely long hours in the fields. Sooner or later the nation will have to come to grips with this problem.

Meantime it is gratifying to note that state child welfare agencies are themselves seeking to take advantage of the more effective child labor regulation possible under the Fair Labor Standards Act. Even more significant, they see the necessity for broadening the scope of federal regulation. The Fifth National Conference on Labor Legislation held in Washington, D. C. in November, 1938, attended by labor and welfare officials of the various states, recommended supplemental state legislation to facilitate cooperation of state agencies in the administration of the child labor provisions of the Act. It urged that all state child labor standards should be raised to those of the Act. Furthermore the resolution significantly took the position that "Every effort be made to complete ratification of the pending Federal Child Labor Amendment." 40

\section{ECONOMIC Adjustments}

With so small a number of child laborers displaced as a result of the Act, it is difficult to see wherein any general economic problems could attend application of its provisions. But taken in its local ramifications, the Act is likely to give rise to many problems. Not the least of these is the economic hardship suffered by those families who for one reason or another are dependent upon a young child's earnings for their principal means of livelihood. By and large, the reason children go to work is family poverty. ${ }^{50}$ Child workers contribute their wages to the home to buy necessities. During periods of widespread unemployment such as we have had in America for the past ten years, instances exist of families whose younger members can find work, at positions that pay a mere pittance, to be sure, while the adult members can find nothing. The solution to the problem of family poverty is certainly not the one advanced for so many years by opponents of regulation at hearings on child labor bills and in the press, that because families needed the children's earnings, children should therefore be allowed to work. Some states went so far as to incorporate this line of reasoning in their laws, by permitting exemptions even for children under 14 years to work in factories. The only defensible procedure is to ban child labor, and then to deal with the cases of economic hardship that arise.

Fortunately today many federal social services exist through which adjustments may be affected for those families or communities which suffer by the displacement of child workers. If a mother with dependent children is involved, mothers' assistance laws furnish relief. State laws are now more adequate due to the aid provided under

\footnotetext{
${ }^{48}$ L UMPRIN AND Dougzas, op. cit. supra note $3 \mathrm{I}, \mathrm{cc} . \mathrm{V}$ and VI.

10 (I939) 38 Mo. Lab. Rev. I3O.

${ }^{80}$ LUMPKIN AND Douglas, op. cit. supra note $3 \mathrm{I}$, at $162 \mathrm{ff}$.
} 
the Social Security Act. When adult members are thrown out of work, the pressure upon younger family members to look for positions is likely to become very great. Some of these cases will be relieved by the existence of new unemployment insurance laws. The most important role will be played by the works program of the Federal Government. When local child welfare agencies come upon families whose children of $\mathrm{I}_{4}$ or $\mathrm{I}_{5}$ are displaced by reason of the prohibitions in the Fair Labor Standards Act, if the parent can find no employment in private industry, then he can be aided in finding work through local WPA authorities. The task of enforcing the child labor provisions of the Act would be very much harder if we did not have a federal works program.

When more headway has been made in the determination of occupations hazardous to minors of $\mathrm{I} 6$ and $\mathrm{I} 7$, some difficult local situations may well arise as a result. If in a town of few industries, for example, one of ranking importance were found to be hazardous for young people, and consequently numbers of young workers in the locality were displaced, a major social problem could develop, requiring a firstrate community program for its solution. Apparently the Children's Bureau recognizes some responsibility in situations of this type to aid state agencies in working out programs. ${ }^{51}$ No doubt the help of agencies such as the National Youth Administration might also be enlisted.

The minimum wage provisions of the Fair Labor Standards Act should further facilitate adjustments. Generally speaking, young workers' wages tend to be very low. Since the minimum wage provisions of the Act apply regardless of age, ${ }^{52}$ it is reasonable to suppose that as a result of federal wage minimums, in many cases the wages of young people will be higher than hitherto. By so much would the economic situation of some families at least be improved. It is possible that young workers may suffer some discrimination under Section $\mathrm{I}_{4}$ of the Act, which provides special treatment for learners, apprentices, and handicapped workers. It permits the Wage and Hour Division to set wages lower than the minimum wage for workers in these classifications. Under NRA codes some employers were found who took advantage of apprenticeship and learner exemptions to hire experienced workers at a lower-thanminimum wage. Something like that might happen to young workers under Section $\mathrm{x}_{4}$, on the part of employers with a disposition to try to circumvent the intent of the Act. No doubt such instances will not be common, and in general the wages of young people under 18 years in interstate industries would tend to rise.

Minimum wage provisions of the Act may have a further wholesome influence. For insofar as young workers are paid the same wage as older, more experienced workers for the same operation, there is no longer a premium on the employment of inexperienced young people under I8. This should in the long run tend in the direction of decreasing the demand for young workers. Thus it would help to accomplish the purpose of the child labor provisions of the Act, so far as possible to eliminate oppressive child labor.

oz U. S. Children's Bureau, Memorandum, supra note 6.

E2 U. S. Department of Labor, A Ceiling for Houtrs, A Floor for Wages, and A Break for Children, (leaflet, 1938) Io. 